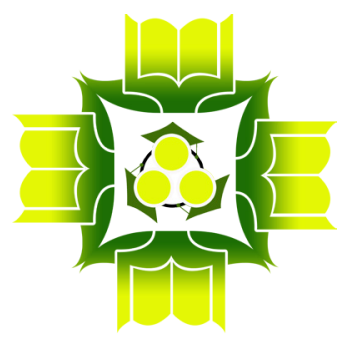

\title{
THE INFLUENCE OF FLIPPED CLASSROOM TOWARDS STUDENTS' MOTIVATION AND LEARNING OUTCOME IN MATHEMATICS: A CASE OF STUDENTS IN SD HJ ISRIATI BAITURRAHMAN 1 SEMARANG
}

\author{
Andrian Gandi Wijanarko \\ INISNU Temanggung, Temanggung, Jawa Tengah \\ andriangandi4@gmail.com \\ Mahardika Ganeswara \\ SD Hj Isriati Baiturrahman 1, Semarang, Jawa Tengah \\ ganeswaramahardika@gmail.com
}

\begin{abstract}
The research problem of this study is whether the implementation of flipped classroom affects the students' motivation and achievements, whether there is the influence of motivation on students' achievement in Mathematics of the fourth grades students of SD Hj. Isriati Baiturrahman 1 Semarang? This research is a quantitative experimental research. The research design is quasi experimental research using non-quivalent control group design. The samples were used as the experimental class and control class with total of 68 students. The $\mathrm{T}$ test results show $\mathrm{t}$ count $>\mathrm{t}$ table $(3.608>1.665)$. In conclusion flipped classroom influence on students' motivation. The T test results show $t$ count $>t$ table $(1.854>1.665)$. In conclusion learning flipped classroom effect on student learning outcomes. Significance test analysis results obtained $\mathrm{F}$ count $>\mathrm{F}$ table $(3113.84>4$, 14), it means a significant regression equation. Analysis results obtained coefficient of determination $\mathrm{R} 2=0.7534=75 \%$. In conclusion there is an influence of learning motivation on Math learning outcomes.
\end{abstract}

Keywords: Flipped Classroom, Motivation, Learning Outcomes. 


\section{Abstrak}

Permasalahan yang dibahas dalam penelitian ini adalah "Apakah penerapan flipped classroom dapat berpengaruh terhadap motivasi siswa, dan hasil belajar, serta apakah ada pengaruh motivasi belajar terhadap hasil belajar matematika siswa kelas IV SD Hj. Isriati Baiturrahman 1 Semarang?". Penelitian ini merupakan penelitian eksperimen dengan pendekatan kuantitatif. Desain penelitian ini quasy exsperimental design dengan jenis nonequivalent control group design. Sampel yang digunakan sebagai kelas eksperimen dan kelas kontrol berjumlah 68 siswa. Hasil perhitungan uji $t$ diketahui $t_{\text {hitung }}>t_{\text {tabel }}(3,608>1,665)$. Kesimpulannya flipped classroom berpengaruh terhadap motivasi belajar siswa. Hasil perhitungan uji $t$ diketahui $t_{\text {hitung }}>t_{\text {tabel }}(1,854>1,665)$. Selain itu, flipped classroom berpengaruh terhadap hasil belajar siswa. Hasil analisis uji signifikasi persamaan regresi signifikan $F_{\text {hitung }}>F_{\text {tabel }}(3113,84>4,14)$. Hasil analisis koefisien determinasi diperoleh $R^{2}=0,7534=75 \%$. Artinya ada pengaruh motivasi belajar terhadap hasil belajar matematika.

Kata kunci: Flipped Classroom; Motivasi; Hasil Belajar

\section{INTRODUCTION}

The Covid-19 pandemic gives complex challenges for education in Indonesia. This doesn't simple to changes the pattern of learning, which is usually be conducted face to face then mutated into online learning. The implementation of online learning demands teacher's competencies to determine proper design \& strategic of learning.

The nucleus (important things) of learning centered on the process of learning it selves (Haber-Curran, 2015). Improving the quality of learning becomes the main priority to makes students reached their competencies. In this era of globalization, a lot of technology is used by teachers to support the process and improve the quality of learning (Rusnawati, 2020). Internet, smartphones, and computer devices can be used as online learning tools. Students can communicate with teachers through several application media (Raniah et al., 2021). Technology can connect teachers and students in learning (Ahsani \& Mulyani, 2020). There are several alternatives in utilizing technology, including by utilizing digital literacy according to the 4.0 generation (Hanik, 2020). Recently emerged policies to apply online learning, however practically there are several problems that must be faced by teachers \& students. 
Based on UNICEF's survey about the implementation of online learning obtained data that $66 \%$ students faced obstacles on online learning (Kasih, 2020). As for the problems faced by the student is the guidance that they received from teachers did not optimal. Practically, the students felt that the guidance given was not optimal because interaction between students \& teachers limited by gadget. In addition, bad internet access affects too. Indonesia's demographic is very diverse, it resulted in the limited internet access in every regions. The intensity of an area that has to limited access a lot more than has good access, no wonder if $87 \%$ students really want back to school/madrasah soon (Kasih, 2020). The problem of limited knowledge of technology, limited online learning experience and limited infrastructure in learning (Anam \& Hanik, 2020).

The result of observation \& interviews with teachers that handle IV grade elementary school, Hj. Isriati Baitturahman I Semarang, showed that there are several obstacles during online learning, such as: first of all, the result of studies did not meet as expected. This is evidenced by some students who still have not reached the minimum completeness criteria. Nowadays, conditions during pandemics resulted in the process of learning is not optimal, this is shown with the motivation do not meet target achievement. The 2nd one, the teachers have limitation on designing online learning. New habit must be acted upon teachers with change the pattern of learning and increase self-potential about designing online learning. But the diversity resources background of teachers will sway the process and also the results of learning. It also affects discrepancy motivation and result of students who teach by that teacher. The 3rd one is the limitations in conducting special guidance for student. This condition is also change the pattern assistance between given by teacher and parent. It will be needed a better communication between teacher, parent and student. In the process of communication, the teacher must be able to become a good facilitator, so it will be bring a good coordination and the process of learning will be optimal. These several problems indicate that online learning lacking in empower students' competency, especially in Mth's subjects about common and compound fraction.

Learning mathematics having the characteristics of abstract object, resting on agreements, deductive pattern, and consistent (Isrok'atun, 2021). Thus, Math's having a conserved regularity surrealism based on a pattern so that concept is 
intertwined. Certainly, hopefully there are real experiences and involvement of learning environment. (Retnanto, 2016) stated that real activities carried out together will provide meaning and remembered in a long time.

In this pandemic situation, the process of learning changed drastically. However, it does not reduce the educational environment in supporting to supporting student's learning process. Such conditions will certainly be more worrying if it drags on for too long. (Philip Kotler, 2009) revealed that various kinds of changes will turn into new habit. In the future, the learning environment must be ready in adapting and face the dynamics of education.

The quality of education is also determined by the participation of internal and external stakeholders (Prastowo, 2018). If it going to be done so well, it will give satisfaction and foster trusted from students and parents to the educational services provided by the madrasah or school itself. This state also in line with (Ahsani, 2020) students should be ready to face future challenges that are very critical; thereby in the future they will be growth as preeminent student. Definitely, this requires the role of education center in making it happen, both boldly and attractively.

According to (Susanti, L, et al., 2019) learning using a mixed approach (online and offline) called as flipped classroom. (Huzaima Mas'ud, 2018) asserts that the flipped classroom is a way that teachers can provide by minimizing the amount of direct instruction in their teaching practice while maximizing interactions with each other.

The implementation of flipped classroom has a quite different structure, students should prepare for next lessons, and then teachers provide opportunities for students to actively participating in class learning (Keengwe, 2014). This pattern distinguishes it from structures in other school; students only listen to the teacher during delivering material. In addition, there are discussion forum and also brief activities for students. Thereupon outside the classroom, students practices to solving problems. (Nwosisi C, et al., 2016) has view that flipped classroom is based on the teacher's change from being wise on stage to guidance on the side, allowing them to work both individually and also along with group of students throughout the learning activities. 
Research that conducted (Lanqin Zheng, et al., 2020) flip classroom was able to improve learning motivation. Further Research (Nouri, 2016) dan (Gawise, 2021)is effective in improving learning outcomes. Moreover, (M. Eko Arif Saputra 2018) conducted flipped classroom research use video learning effective in understanding concepts. In addition, (Unal, Zafer; 2017) shows that student learning outcomes using flipped classrooms are higher, student perceptions are more positive, and teacher satisfaction is higher than the traditional model.

According to researchers, some of these studies have shown positive and significant results, but have not involved the role of parents in the implementation of the learning process. Furthermore, the comparison class also has different actions. In addition, the technology used is limited to learning videos, not yet facilitating interactive online activities.

Considering this, the researcher implemented a flipped classroom with parental guidance. (Gasong, 2018) revealed that success in the teaching and learning process is determined by several factors, both from within and outside students. This research is more in-depth on the collaborative role of the education tricenter in implementing the flipped classroom to determine the effect of motivation and student's learning outcomes.

In short, the researches state that this research studies is more in-depth on the collaborative role of education three-center in implementing the flipped classroom. There are several reasons to implementing this research. First of all, encourage the role of parents in giving attention to their children. THe 2nd one, growing student's skill in online learning carried out by teachers. The 3rd one, improve the relationship of three-center education in the learning process. In line with (Epstein, 2016) parental involvement in child's learning process is like parents who are purified again as educators. It means that parents also carry out supervision, learning resources, facilitators and substitution of teachers' classroom at home.

Practically, students participate in preparing for learning through video display, powerpoints and e-learning access to obtain learning resources with parental assistance at home. In line with the view of (Fauzan, 2017) that in the Industrial Revolution Era 4.0 and Society 5.0 demands on the rule of educational 
institutions and learning environments to be able to produce humans who not only master in science and professional skill but also apply the noble values of religion and are practiced by students at every steps of their life.

Generally, learning process also carried out in class, but due to the Covid-19 pandemic, school also need to prepare preventive actions. Wisdom is need in implementing health protocol (wearing masks, maintaining distance, washing hands, staying away from crowds, and limiting mobility). In addition, with the 3T discipline (testing, tracing, and treatment) thereby will flatten out virus' transmission and preserves the health of students and teachers. In the implementation, teachers and students discuss to solve the problems based on the homework given and the topic to be discussed.

This research is also unique, including; first of all is the application of activities in accordance with health protocol. Before carrying out offline activities, all educators and education staff should be received vaccinations. Educators and education staff are expected to have immunity and be able to ward off viruses. The 2nd one is schools also use Genose for students and educators to be able to detect the early stages of Covid-19 thus it does not enter school environment (Wibisono, 2021). The utilization of this tool and the availability of infrastructure will provide a sense of secure for students and parents. Third, school must be cooperating with the government in providing health services if there are students or teachers who are infected to Covid-19. The 4th one is students also use digital information and communication technology in the Industrial Revolution Era 4.0 and Society 5.0 through the Zoom and Youtube application with parental assistance. Fifth, during offline learning at school, students must be applying strict health protocol with restrictions on the number of student which are arranged in turns.

Considering this, the researcher implemented flipped classroom with parental assistance to determine the effects on motivation and learning outcomes of IV-th grade Elementary School Hj Isriati Baiturrahman I Semarang. 


\section{METHODS}

This quantitative research used quasy experimental design shaped nonequivalent control group design. Research uses samples taken randomly from a certain population. The type of the designs is a posttest-only control design with the following division; there are two classes. After being randomly selected, the first class is treated (experimental class) using a flipped classroom with parental involvement and the control class using flipped classroom without parental involvement. Sampling uses saturated sampling, namely the object to be studied is use as sample (Sugiyono 2016). The population in this study was IV'th grade students of $\mathrm{Hj}$ Isriati Baiturrahman I Elementary School Semarang. the research subjects were 68 students.

The research carried out from April 26 to May 10, 2021. Learning outcomes in this study were limited to the cognitive aspect by using a written test to determine the value of students' Math learning outcomes in the experimental class and the control class. Questionnaires are used to determine students' learning motivation.

The analysis of the instrument test consists of testing the motivational instruments which includes the validity test using the product moment correlation formula, to obtain a valid question. The result of the reliability test used the splithalf method; the formula used was K-R. 20 (Sugiyono, 2016), obtained r-count = 0.8394 , meaning that the question instrument is said to be reliable.

The data analysis technique used consists of preliminary analysis and final analysis. Preliminary analysis contain of preliminary normal test, homogeneity test, and average similarity test. While the final analysis contain of final normal test and homogeneity test, also hypothesis testing which consists of average difference test of learning motivation, the average difference test of learning outcomes and simple linear regression analysis.

The analysis of the final normality test used the Liliefors formula. After knowing the normality the homogeneity test was carried out using the F test formula, so therefore it was known that both classes had the same variance. Thereafter test the difference in the average analyzed by using the two sample t-test formula. 
First hypothesis testing, to find out the difference in the average motivation to learn Math between the experimental class and the control class, using the two samples $t$-formula at a significance level $a=0,05$. To determine the percentage of student's learning individually and clasiccally, it was analyzed using the following formula (Sugiyono, 2016):

$$
\text { prosentase }=\frac{n}{N} \times 100 \%
$$

The criteria for interpreting student learning motivation in this study use the following table (Arikunto, 2007):

Table 1. Criteria of Motivation

\begin{tabular}{cc}
\hline Percentage & Criteria \\
\hline $81-100 \%$ & Exceedingly high \\
\hline $61-80 \%$ & High \\
\hline $41-60 \%$ & Rather \\
\hline $21-40 \%$ & Shortage \\
\hline
\end{tabular}

Students' motivation indicators are indicated by enthusiasm indicators for learning, doing assignments, actively asking and answering during discussions, being competed to get maximum scores.

The 2nd testing hypothesis is to find out the difference in the average learning outcomes of Math between the experimental class and control class, used a two-sample t-test formula at a significance level of $a=0,05$.

The 3rd hypothesis testing is to determine the effect of learning motivation on learning outcomes by using a simple linear regression analysis formula.

\section{RESULT AND DISCUSSION}

\section{Normality Test Results}

This part shows the preliminary data condition of the forth grade students of Hj.Isriati Baiturrahman 1 Elementary School Semarang. According to the result of the data analysist in the early stage from Mathematics middle test Assessment. 
The calculation results of normality test from the early experimental class can be stated that $L_{o}<L_{\text {tabel }}$ is $(0,0700<0,1498)$ so the normal distribution data (it is from the same population). The calculation results of normality test from the control class can be stated that $L_{o}<L_{\text {tabel }}$ is $(0,1096<0,1542)$ so, the normal distribution data (the sample is from the same population). According to the calculation results of variant test can be stated that $\mathrm{F}_{\text {hitung }}<\mathrm{F}_{\frac{1}{2}\left(\mathrm{v}_{1} \mathrm{v}_{2}\right)}$ is $(1,06<1,79)$. It means both samples are homogeneus. According to the calculation results of the average similarity test of the two classes can be stated that $t_{\text {hitung }}<t$ tabel is $(0,467<1,665)$ so Ho is accepted. It means both samples have the same average.

Then, the two classes were given the different treatment. Researchers observed students' learning motivation during mathematics learning process in both classes In the end of learning process, teacher gives posttest in both classes to know the difference results of the both classes.

The two classes were analyzed the final stage using the normality test and the variance similarity test. The calculation of normality test from experimental class can be stated that $L_{o}<L_{\text {tabel }}$ is $(0,1493<0,1498)$ so, the normal distribution data (the sample is from the same popolation). The calculation results of normality test from the control class can be stated that $L_{o}<L_{\text {tabel }}$ is $(0,1012<0,1542)$ so the data is normally distributed (It is from the same population). According to the calculation results of variant test can be stated that $F_{\text {hitung }}<\mathrm{F}_{\frac{1}{2}\left(\mathrm{v}_{1} \mathrm{v}_{2}\right)}$ is $(0,51<1,79)$ It means both samples are homogeneus. (it has the same variant).

\section{Hypothesis Test Results}

\section{a) The Effect of Flipped Classroom on Students' Learning Motivation}

According to the calculation results two samples of $\mathrm{t}$ test with $\mathrm{a}=$ 0,05 , distribution list $\mathrm{t}$ with $\mathrm{dk}=(35+33)-2=66$, can be stated $\mathrm{t}_{\text {hitung }}>$ $t_{\text {tabel }}$ is $(3,608>1,665)$ so Ho is rejected, It means the average of learning motivation in the experimental class and control class are different. The data that has been analyzed shows that the learning motivation of the experimental class students is higher than the control class. The percentage of students' learning motivation in the experimental class is $77 \%$, while the control class is $68 \%$. The differences in student learning motivation can be seen in the form of a diagram below: 
Tabel. 2 Student's learning motivation

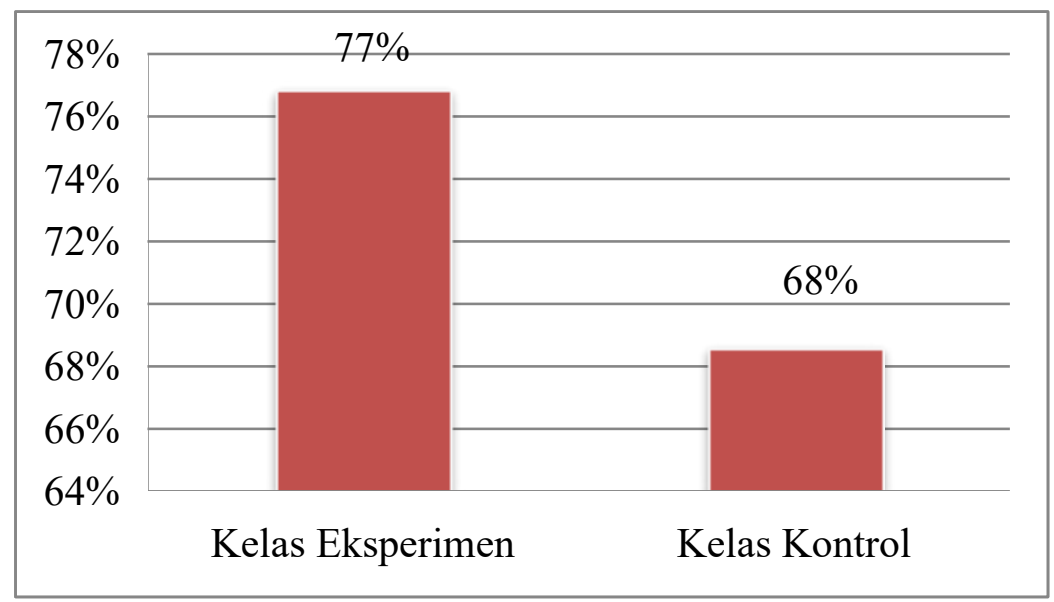

The results of data analysis of student learning motivation in the experimental class found 35 students, there were 13 students in the very high learning motivation category, and 22 students in the high motivation category. While in the control class, which amount of 33 students, there were 5 students with very high learning motivation category, 19 students with high motivation category, and 9 students with moderate category.

The difference in learning motivation between the experimental class and the control class are because the application of the flipped classroom with parental assistance is able to create a pleasant, conducive, meaningful class atmosphere that can train students to work together in solving problems with their groups. Based on the observation of the experimental class learning motivation, there were several activities with the students enthusiasm in following each stage carried out by the teacher in implementing the flipped classroom with parental assistance. This is showed the student's activities who are enthusiastic to learn, do assignments, actively ask and answer during discussions, and able to compete to get maximum scores.

The results of the observation of learning motivation in the control class showed that the teacher could apply the flipped classroom according to the planned syntax, but there were some students who were not active either asking, answering, doing assignments, and competing in these 
activities. Lack of student motivation in learning process causes students to be less active in the learning process, besides that because there is no parental involvement in the learning process.

This research activity is in line with(Lanqin Zheng, et al., 2020) flipped classroom is able to give an impact on student's learning motivation. However, there are difference internal and external integration that well executed. This is indicated by the role of parents in providing motivation from parents to students. The involvement of parents in this research, which researchers found there was special attention from parents in analyzing the strengths or weaknesses of children. Parents are also able to provide a learning approach by coordinating with teachers through gadgets or direct coordination.

\section{b) The Effect of Flipped Classroom on Students' Cognitive Aspect Learning Outcomes}

The application of the flipped classroom method with parental assistance also affects students' cognitive learning outcomes. According to the calculation results two samples of $t$ test with $\alpha=0,05$, from the list distribution of $\mathrm{t}$ with $\mathrm{dk}=(35+33)-2=66$, stated that $\mathrm{t}_{\text {hitung }}>t_{\text {tabel }}$ is $(1,854$ $>1,665)$ so Ho is rejected. It means that the average of learning outcomes of experimental class and control class are different.

Based on the data of learning outcomes that have been analyzed, the difference in the average learning outcomes of experimental class and control class students is obtained. The average of experimental class is 77,11 , while, the average of control class is 68,94 . The average learning outcomes of the experimental class are higher than the average of the control class. The difference in learning outcomes can be described in the form of a diagram below. 
Tabel. 3 The average student's learning outcomes

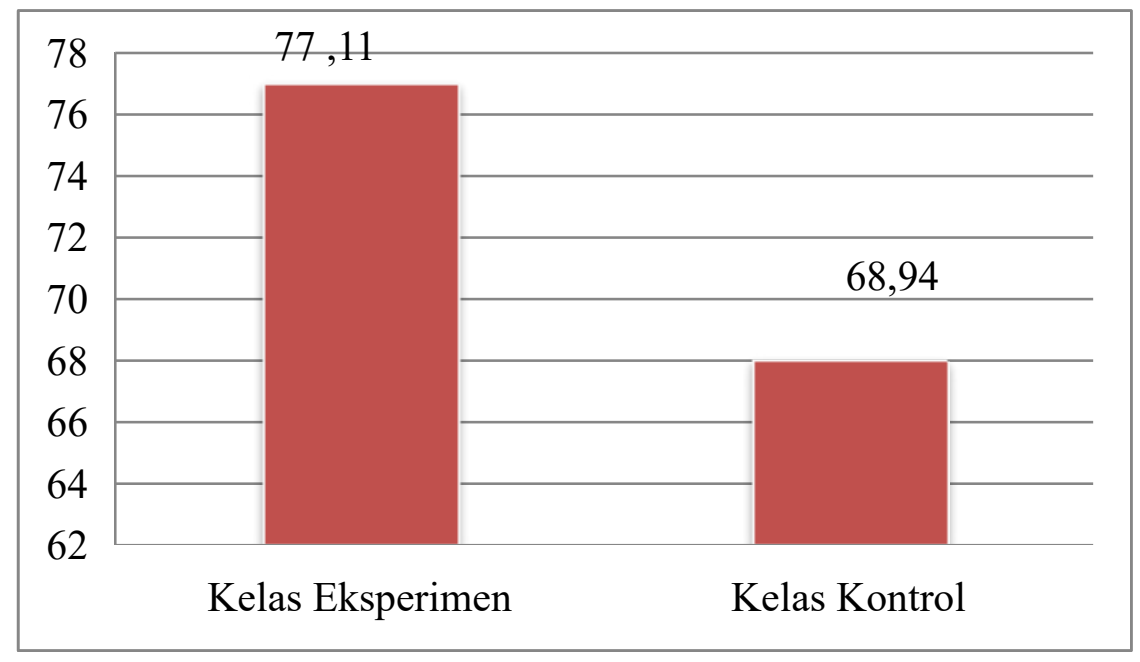

The application of the flipped classroom with parental assistance has been proven to create a participatory learning environment and creates reinforcement so that the experimental class learning outcomes are higher than the control class. The difference in learning outcomes between the experimental class and the control class is because the application of the flipped classroom with parental assistance makes learning more fun and gives an impression to students. Learning is more accessible using android devices, laptops, and computers. Not only students, parents and teachers are also very helpful because they can accompany and monitor students when accessing e-learning provided by the school. This is what control class differs from, because students learn without special assistance from their parents, so they have several obstacles in the learning process and results. Research (Nouri, 2016) and (Gawise, 2021) shows a significant differences between the flipped classroom and the comparison class. The research conducted has both similarities by comparing the two classes, but the difference is the researcher uses a flipped classroom with parental assistance and a flipped classroom without parental assistance. In line with (M. Eko Arif Saputra, 2018) as a researcher who research the understanding of mathematical concepts, this study focuses on the material of proper fraction and mixed fractions. 
c) The Impact of Motivation to Cognivite Aspects Learning Outcomes.

There is an impact of learning motivation on students learning outcomes. This is based on the calculation results that in the linear equation test, it shows that the calculated $\mathrm{F}$ is 2,12 , then compared with $\mathrm{F}$ table seen at significant $\mathrm{a}=5 \%$ with $\mathrm{db}$ numerator $\mathrm{db}_{\mathrm{t}}=13$ and denominator $\mathrm{db}=20$, obtained $\mathrm{F}$ table $=2,25$. Because $\mathrm{F}$ count $<\mathrm{F}$ table, namely $(2,12<2,25)$, then Ho is rejected, meaning it is a linear equation.

Furthermore, in the significance test the result of the analysis showed that the calculated F was 3113,84 , then compared with the F table seen at significant $\mathrm{a}=5 \%$ with $\mathrm{dk}$ in the numerator $\mathrm{db}_{\mathrm{reg}}=1$ and $\mathrm{dk}$ in the denominator $\mathrm{db}_{\text {res }}=33$, obtained $\mathrm{F}$ table $=4,14$. Because $\mathrm{F}$ count $>$ F table, namely $(3113,84>4,14)$, then Ho is rejected, meaning that the equation is significant. The result of the determination coofficient analysis obtained $\mathrm{R}^{2}=0,753$ or $75 \%$. This is shows that there is an impact of learning motivation to the learning outcomes by $75 \%$.

Thereby, it can be stated that learning motivation has an impact of $75 \%$ on learning outcomes and the remaining $25 \%$ is caused by other factors that the authors did not observed. In line with (Keengwe, 2014) students prepare themselves carefully will provideopportunities for active participation during learning process. The implementation of flipped classroom learning model with parental assistance on eksperimental class might create a pleasant classroom atmosphere; students are more interested and motivated in following every step of the Math's learning activities carried out by the teacher.

Researchers have tried to design research that is in compatible with the syntax or stages of research, nevertheless it is posibble that there are also frailty, laxity and limitations. The frailty of the study includes the following. First of all, this research is limited to the scope of the problem, only about cognitive learning outcome on Math. The $2^{\text {nd }}$ one is the flipped classroom applied by the teacher was only carried out on IV grade students of Hj Isriati Baitturahman I Elementary School Semarang. Pursuant to the researcher, in case of the research carried out 
with a larger number of schools, it will provide diverse result. However, because it is still in the pandemic period, not many schools have a proper resources and infrastructures to implement this activites. Third, the coordination carried out by the researcher with the IV grade teacher regarding learning activities using then flipped classroom has not been fully understood by the model teacher, allowing that the implementation of learning process is not optimal. On that occasion, the researcher was intensive to coordinate with the teacher when carrying out self-reflection about the frailty in the learning process that had been implemented so that it able to be corrected on the next meeting. Fifth, the limited time and pandemic period caused a lack of supervision from the teacher on the activities carried out by students in the learning process using the flipped classroom.

\section{CONCLUSION}

The conclusion of this study; (1) The application of flipped classroom with parental assistance impact on the motivation of study (2) The implementation of flipped classroom with parental assistance influences study result the learning outcomes on common and compound fractions stuff. (3) There is an impact of motivation on the learning outcomes of IV gradestudents of $\mathrm{Hj}$ Isriati Baitturahman I Semarang. Based on the results of the research, the suggestions that writer able to convey include that teachers should be able to cooperate with parents in monitoring students during learning process at home. In additions, teachers, parents and students need to follow up by analyzing students' requirements according to their needs. Thereafter, further research is needed related to the impact of online learning to learning outcomes in other aspects. 


\section{REFERENCES}

Ahsani, E. L. F. (2020). Analisis Bahan Ajar Kurikulum 2013 Berbasis Multiple Intelligence Kelas IV. 8, 19-36.

Ahsani, E. L. F., \& Mulyani, S. E. (2020). The Implementation of Distance Learning Based E-Learning for Developing Student's Life Skills. Didaktika: Jurnal Pendidikan Sekolah Dasar, 3(2), 115-120.

Anam, S., \& Hanik, E. U. (2020). Problematika Kebijakan Pendidikan di Tengah Pandemi dan Dampaknya Terhadap Proses Pembelajaran di Sekolah Dasar. Jurnal Pendidikan, 2(2), 24-24.

Arikunto, S. \& J. (2007). Evaluasi Program Pendidikan. Jakarta: PT. Bumi Aksara. Pt Bumi Aksara.

Christopher Nwosisi, Alexa Ferreira, Warren Rosenberg, and K. W. (2016). A Study of the Flipped Classroom and Its Effectiveness in Flipping Thirty Percent of the Course Content. International Journal of Information and Education Technology, 6(5), 348.

Epstein, J. L. (2016). School, Family, and Community Partnerships Preparing Educators and Improving Schools (2nd ed.). Routledge.

Fauzan. (2017). Integrasi Islam Adan Sains Dalam Kurikulum Program Studi Pendidikan Guru MI Berbasis KKNI. JMIE (Journal of Madrasah Ibtidaiyah Education), 1(1).

Gasong, D. (2018). Belajar dan Pembelajaran (1st ed.). Deepublish.

Gawise. (2021). Efektifitas Pembelajaran Model Flipped Classroom masa Pandemi Covid-19 terhadap Hasil Belajar di Sekolah Dasar. Edukatif: Jurnal Ilmu Pendidikan, 3(1), 246-254.

Haber-Curran, P. (2015). Student-centered transformative learning in leadership education: An examination of the teaching and learning process. Journal of Transformative Education, 13(1).

Hanik, E. U. (2020). Self Directed Learning Berbasis Literasi Digital Pada Masa Pandemi Covid-19 Di Madrasah Ibtidaiyah. ELEMENTARY: Islamic Teacher Journal, 8(1), 183. https:/ / doi.org/10.21043/ elementary.v8i1.7417

Huzaima Mas'ud, H. D. S. (2018). The implementation of flipped classroom learning model using moodle to increase students' higher order thinking skills. Journal of Educational Science and Technology, 4(3).

Isrok'atun, A. R. (2021). Model-Model Pembelajaran Matematika (1st ed.). Bumi Aksara. 
Kasih, A. P. (2020). Survei UNICEF: 66 Persen Siswa Mengaku Tak Nyaman Belajar di Rumah Survei UNICEF: 66 Persen Siswa Mengaku Tak Nyaman Belajar di Rumah. Kompasiana.

Keengwe, J. (2014). Promoting Active Learning through the Flipped Classroom Model. IGI Global.

Lanqin Zheng, Kaushal Kumar Bhagat, Y. Z. and X. Z. (2020). The Effectiveness of the Flipped Classroom on Students' Learning Achievement and Learning Motivation. Educational Technology \& Society, 23(1), 1-15.

M. Eko Arif Saputra, M. M. (2018). Efektivitas Model Flipped Classroom Menggunakan Video Pembelajaran Matematika terhadap Pemahaman Konsep. Desimal: Jurnal Matematika, 1(2), 173-179.

Nouri, J. (2016). The flipped classroom: for active, effective and increased learning - especially for low achievers. International Journal of Educational Technology in Higher Education, 33(13).

Philip Kotler, J. A. C. (2009). Chaotics:the bussines of managing and marketing in the age of turbulence (1st ed.). Library of Congress Cataloging.

Prastowo, A. (2018). Sumber belajar dan pusat sumber belajar: Teori dan aplikasinya di sekolah/madrasah (1st ed.). Prenadamedia group.

Raniah, A., Prantista, J. R., Alfiana, D. P., Aghisni, S. F., \& Ahsani, E. L. F. (2021). Dampak Pandemi terhadap Pemanfaatan e-Learning pada Sekolah Dasar di Den Haag. Islamic Review: Jurnal Riset Dan Kajian Keislaman, 10(1), 111124. https:/ / doi.org/10.35878/islamicreview.v10i1.251

Retnanto, A. (2016). Aktualisasi Pendekatan Contextual Teaching and Learning(CTL) Pada Pembelajaran Mata Kuliah Metodologi Penelitian Pendidikan di STAIN Kudus Tahun 2016. Quality Journal by Pascasarjana IAIN Kudus, 4(1), 140-162.

Rusnawati, M. D. (2020). Implementasi Flipped Classroom terhadap Hasil dan Motivasi Belajar Siswa. Jurnal Imiah Pendidikan Dan Pembelajaran, 4(1).

Sugiyono. (2016). Metode Penelitian Kuantitatif, Kualitatif dan RED. PT Alfabet.

Susanti, L, Hamama Pitra, D. (2019). Flipped Classroom Sebagai Strategi Pembelajaran Pada Era Digital. Health \& Medical Journal, 1(2).

Unal, Zafer; Unal, A. (2017). Comparison of Student Performance, Student Perception, and Teacher Satisfaction with Traditional versus Flipped Classroom Models. International Journal of Instruction, 10(4), 145-164.

Wibisono, L. (2021). Hendi Coba Genose Untuk Sekolah Tatap Muka Di Kota Semarang. Halosemarang.Id. 